Original Article

\title{
HONEY BEE COLONIES PERFORMANCE ENHANCE BY NEWLY MODIFIED BEEHIVES
}

\author{
Hossam F. Abou-Shaara* \\ Ahmad A. Al-Ghamdi \\ Abdelsalam A. Mohamed \\ Baqshan`s Chair for Bee Research, Plant Protection Department, College \\ of Food and Agriculture Sciences, King Saud University, P.O. Box. 2460, \\ Riyadh 11451, Saudi Arabia \\ *corresponding author: entomology_20802000@yahoo.com \\ Received 01 October 2012; accepted 12 August 2013
}

\begin{abstract}
A b s t act
Honey bees have good thermoregulation and rapidly respond to any changes in the microclimatic conditions of their colonies. However, colony losses can occur during very cold or hot months. Honey bee colonies are often kept in modified beehives during such times to save the honey bees lives. In the present study, the abilities of four beehive types to enhance the performance of two honey bee races (Carniolan and Yemeni honey bees) were compared under hot and arid environmental conditions. The results indicated performance differences between the two races and between the selected beehive types. For the Carniolan honey bees, better results were obtained in colonies provided with insulated cover boxes (ICB) than in thermoregulatory beehives (TBH), insulated beehives with a back drawer (IBD), and normal beehives (NB) in that order. In contrast, better Yemeni honey bee results were obtained in the TBH, followed by ICB, NB, and finally IBD. Maintaining honey bees in a suitable beehive type is a promising method for saving honey bees lives and enhancing their performance under harsh environmental conditions.
\end{abstract}

Keywords: Apis mellifera, harsh environment, honey bees, modified beehive.

\section{INTRODUCTION}

The standard Langstroth beehive is commonly used in beekeeping around the world. However, the challenges of environmental conditions, especially extremely hot or cold weather, have caused many researchers to suggest modifications to the standard beehive. Some standard beehive modifications have enhanced the performance of honey bees under cold conditions. Some examples of these cold-based modifications are heated and heated-fan beehives (Erdogan et al., 2009), beehives containing a device to control the temperature during the winter season (Omran, 2011), and beehives with an automatic system and complex control architecture to improve the wintering process of the honey bees (Zacepins and Stalidzans, 2012). Other modifications have been carried out to boost the performance of honey bee colonies under excessively hot conditions. Beehives with BeeCool devices, which contain solar-powered fans, (Al-Kahtani, 2003) are an example of heat-based modifications. Altun (2012) developed a solar-powered system to control temperature and humidity within the beehives to provide the bees with optimal conditions. Other changes have been made to standard beehives for other purposes, such as changes to facilitate honey bee feeding (AbouShaara, 2011), for controlling small hive beetles (Ellis et al., 2003), to facilitate the collection of honey bee eggs (Omholt et al., 1995), for monitoring colony environments via large controlled containers (Ohashi et al., 2008), or the use of two-frame observation hives. $A$ glass box and wooden frame (Ohashi et al., 2009) enable the monitoring of honey bee activities in such hives (Meitalovs et al., 2009). 
Most of these beehive modifications have intended to help honey bees to regulate their nest microclimate under extreme environmental conditions. Honey bees are known to have a good ability to regulate their nest conditions within an optimal range between 33 and $36^{\circ} \mathrm{C}$ (Kronenberg and Heller, 1982). The regulation is done through cooling or heating behaviors for which a specific thermal-activated receptor in the antennal flagellum has been identified (Kohno et al., 2010). However, the ability of honey bee workers to perform thermoregulation within the colony is negatively affected by extreme conditions. More energy ends up being wasted to either increase the internal temperature during the winter season or reduce the heat burden during the summer season. In arid areas, the situation becomes more complex where high temperatures are accompanied by low humidity. Under such conditions, honey bee workers must regulate the temperature and humidity within the nest. In addition to the effect of temperature on colony activities, humidity is of particular importance for brood development (Kuhnholz and Seeley, 1997; Human et al., 2006) and egg hatching (Doull, 1976; Ellis et al., 2008).

Elevated temperatures have recently been considered a threat to beekeeping. Different regions with honey bee colonies suffer from excessive heat especially during the summer. Included are some countries on the Arabian Peninsula, the Americas, Asia, and Australia.
Saudi Arabia is a country that suffers from high colony losses and low honey bee colony performance during the intense summer season. Not only are the native Apis mellifera jemenitica honey bees of Saudi Arabia affected but also the Carniolan honey bee hybrids imported from Egypt. However, differences between these races in their performance and tolerance to harsh environmental conditions have been reported (Al-Ghamdi, 2005; Al-Qarni, 2006). Therefore, new modified beehives have been made and evaluated to enhance the colony performance. The two honey bee races in harsh environmental conditions were used. The resulting modified beehive most suitable for beekeeping purposes has subsequently been suggested.

\section{MATERIAL AND METHODS}

This research was performed at the apiary of the Bee Research Unit in the Al-Deriyah region of Saudi Arabia. The study was located in a harsh environment with high temperatures, low humidity, and a scarcity of pollen and nectar resources (Fig.1). Control over pollen and sugar feeding was possible in this location. This location was selected to evaluate various beehive types. It was important to see how much the beehives enhance honey bee colony performance under such harsh environmental conditions. A water source, which was approximately $70 \mathrm{~m}$ from the apiary, was available to
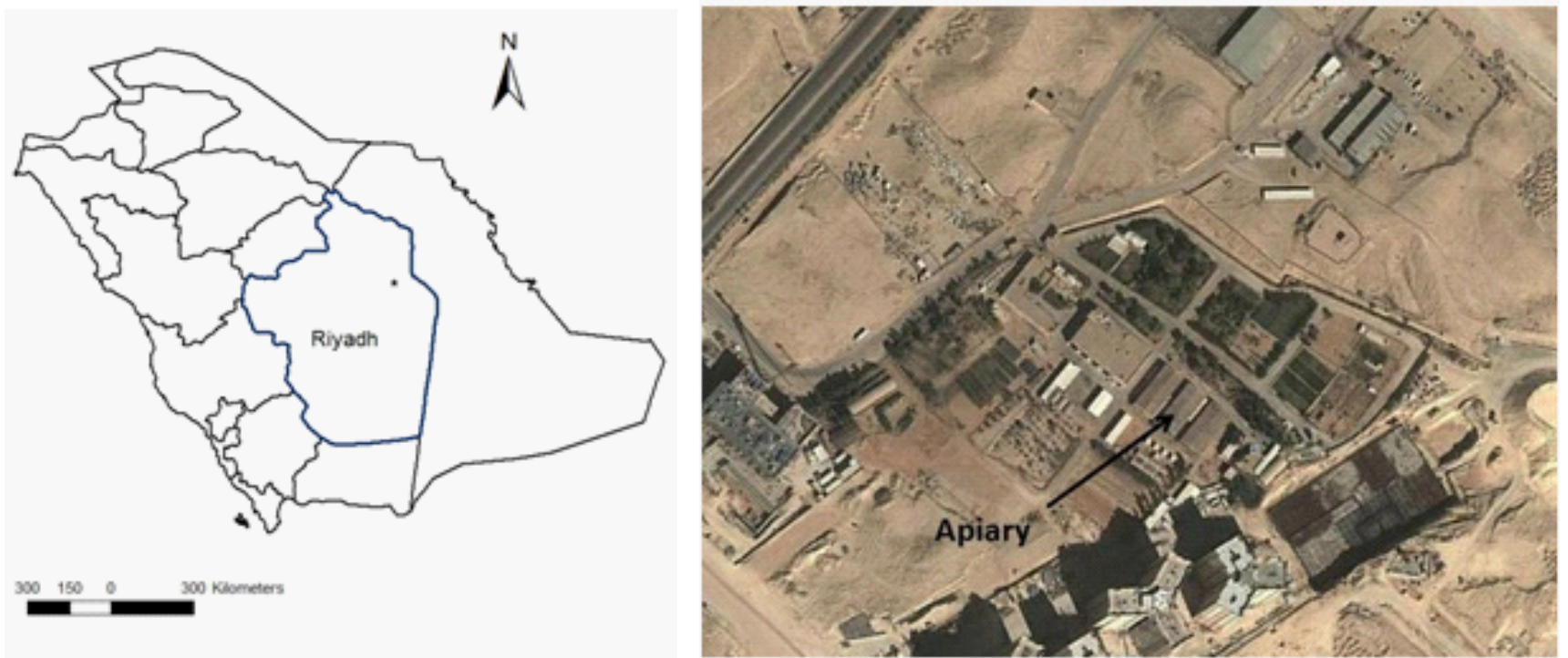

Fig. 1. The approximate site of the apiary location in Riyadh city (left) and the actual site of the apiary from an image of Google Earth taken at the height of $664 \mathrm{~m}$ (right). 
the honey bee workers. The water source was continuous, which is preferable for honey bee workers (Abou-Shaara, 2012).

Two honey bee races were used in this study; the imported Carniolan A. m. carnica honey bees, and the indigenous Yemeni $A$. m. jemenitica honey bees. Each race was represented by 20 colonies. The colonies were placed at the apiary in April, which was 2 months prior to experimentation. The colonies were housed under shaded conditions to relieve the direct impact of solar radiation. The colonies were subsequently adjusted to contain five frames, with three brood combs and two honey and pollen frames. Due to the scarcity of nectar and pollen resources, sugar syrup (50\%) was given to the colonies weekly in open feeding arrangements from two containers, each approximately 15 liters. Furthermore, $116 \mathrm{~g}$ of protein patty (5 pollen: 3 sugar) were added weekly to each colony.

\section{Modified beehives (beehive types)}

Three newly modified beehives were used in the study in addition to the normal Langstroth beehive (NB). The performance of the honey bees housed under harsh conditions within these beehives was evaluated and compared throughout the summer season. Each type of beehive was represented by five colonies per race (40 total colonies). The modified beehives were as follows:

\section{Thermoregulatory beehives (TBH)}

These beehives were provided with a source of humidity and ventilation. The beehives were powered by an electronic controller to keep temperature and relative humidity $(\mathrm{RH})$ around the optimum range (temperature from 32 to $35^{\circ} \mathrm{C}$ and $\mathrm{RH}$ from 75 to $85 \%$ ). Some features of this thermoregulatory beehive were adapted from an invention by A. A. Al-Ghamdi (2012).

Insulated beehive with a back drawer (IBD)

Beehives were provided with a humidity source through the use of a back drawer. The back drawer was filled with water regularly. A half mesh barrier was fixed above the back drawer to separate the hive box from the back drawer. Bee combs were placed above the solid half of the barrier. The hive box was surrounded with an insulation material (Arnon insulation with a $10 \mathrm{~mm}$ thickness, produced by Arnon plastic industries Co. Ltd., Dammam, Saudi Arabia). The general parts of this beehive are shown in Figure 2. Some features of this beehive were adapted from an invention by A. A. Al-Ghamdi and H. F. Abou-Shaara (2012).
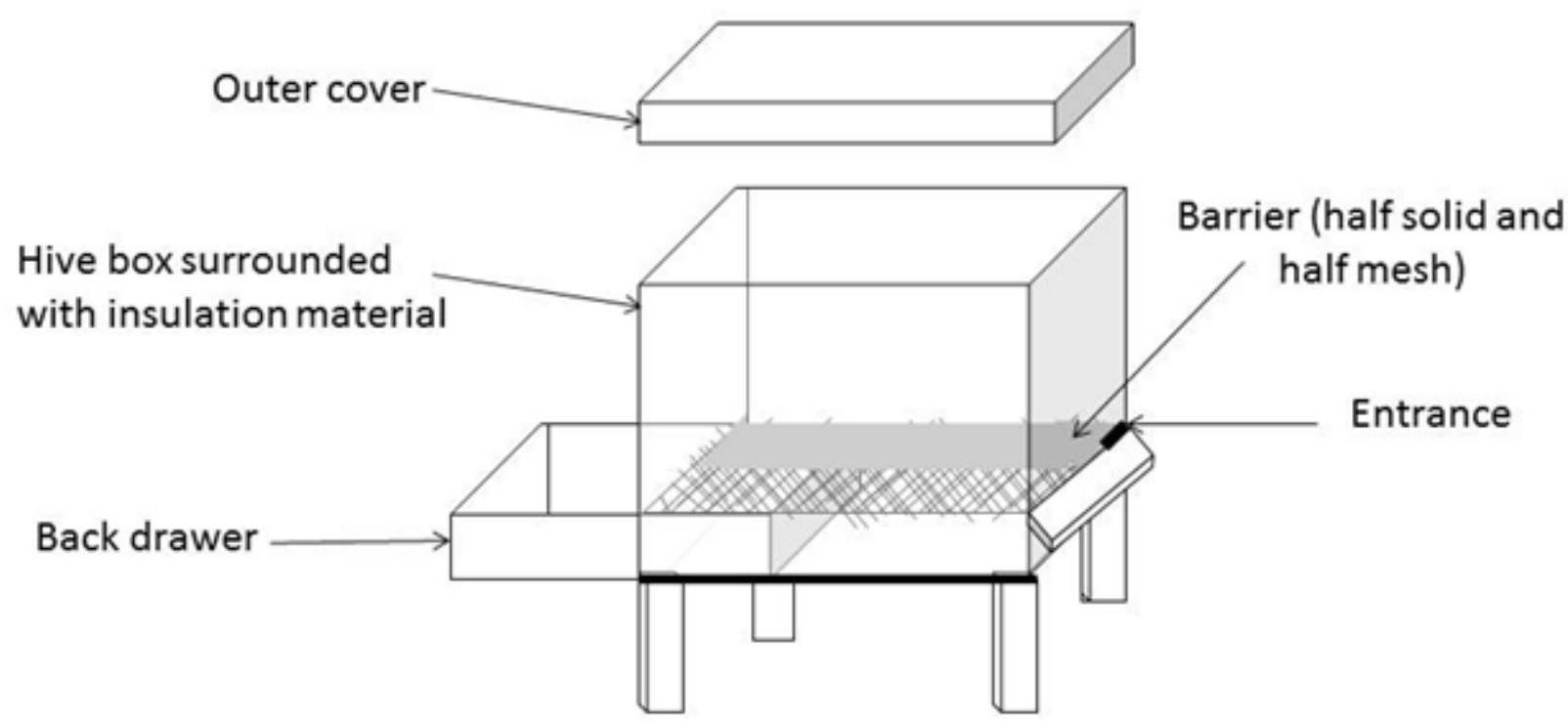

Fig. 2. General parts of insulated beehive with back drawer. 
Insulated cover box (ICB)

$A$ box was designed to cover the entire beehive without interrupting the foraging activity or the beekeeping practices (e.g. hive inspection). The dimensions of the cover box were $81 \mathrm{~cm}$ in length $\times 62 \mathrm{~cm}$ in width $\times$ a height of $72 \mathrm{~cm}$. Ten centimeters of the total height were devoted to the upper cover. The front side of the cover box was empty up to a height of $40 \mathrm{~cm}$ to allow normal foraging by the honey bee workers. This box was partially covered with insulation from the aforementioned source; the outer surface and walls of the box were also covered with insulation (Fig. 3).
Foraging activity

The foraging activity was recorded by counting the foragers departing or returning to the colony for $3 \mathrm{~min}$ from 7 to $9 \mathrm{am}$. The recording was typically done for 2 days per week during the study period. In addition, the ambient temperatures were recorded simultaneously with the foraging activity, using an immediate measuring device (HD 8501). The temperature ranged from -50 to $+150^{\circ} \mathrm{C}$. The correlation coefficient (r) between the foraging activity and the ambient temperature was subsequently calculated.

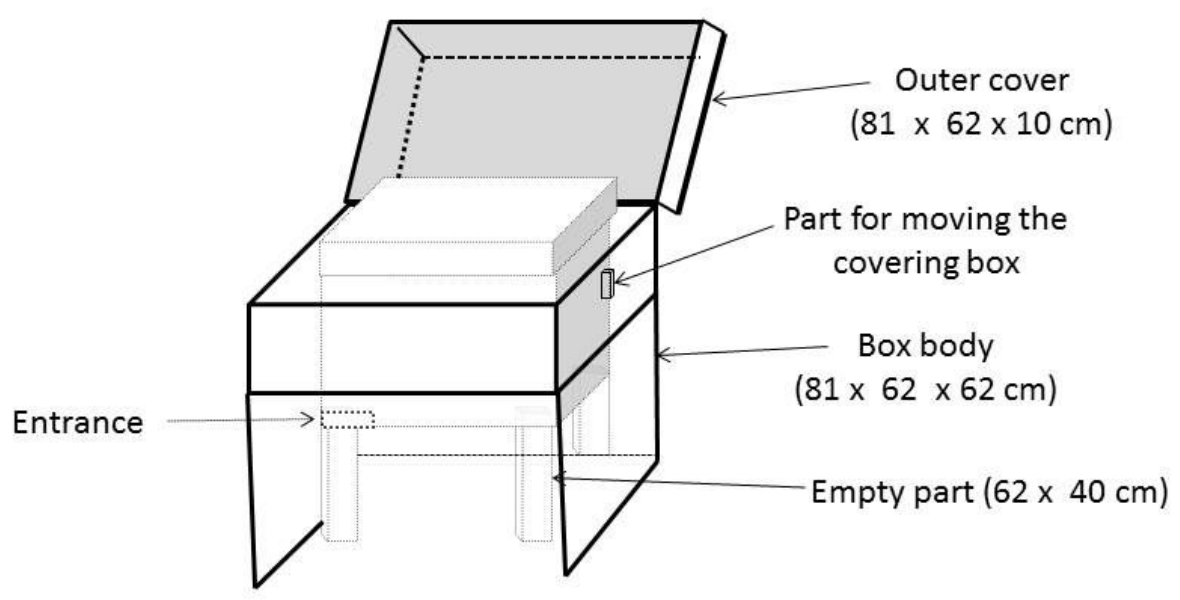

Fig. 3. Insulated cover box.

\section{Measuring parameters}

Internal activities of honey bee colonies

The areas for the sealed brood, stored pollen, honey, and bees (colony strength) were measured using a Langstroth frame divided into square inches (Jeffree, 1958) at 12-day intervals. The square inches were subsequently transferred into $\mathrm{dm}^{2}$ (the values were divided by 15.5) for sealed brood, stored pollen, and honey areas while the area for the bees was transferred into numbers (the values were multiplied by 10). The approximate mean number of bees per square inch for the two races was 10 bees. Yemeni honey bees are known to be smaller than the Carniolan honey bees (Abou-Shaara and Al-Ghamdi, 2012). Therefore, the mean number of bees per square inch was used to facilitate mean comparisons between the two races.

\section{Emergence rate}

Approximately 100 sealed brood cells were marked on a transparent plastic sheet for three colonies per treatment at the beginning of each month throughout the study period. Twelve days after marking the sealed brood cells, the number of emerging bees was calculated using the same transparent plastic sheet. The emergence rate was then calculated by dividing the number of unsealed cells by the total number of marked cells and multiplying by 100 to present the results as a percentage. This parameter was measured to indicate the suitability of the microclimatic conditions within each treatment for the development and emergence of honey bee workers. An emergence failure during the 12-day period for the randomly marked sealed cells provided an indicator of the microclimatic deviations within the colony, which directly or indirectly impacted the development and emergence of the honey bee workers. 


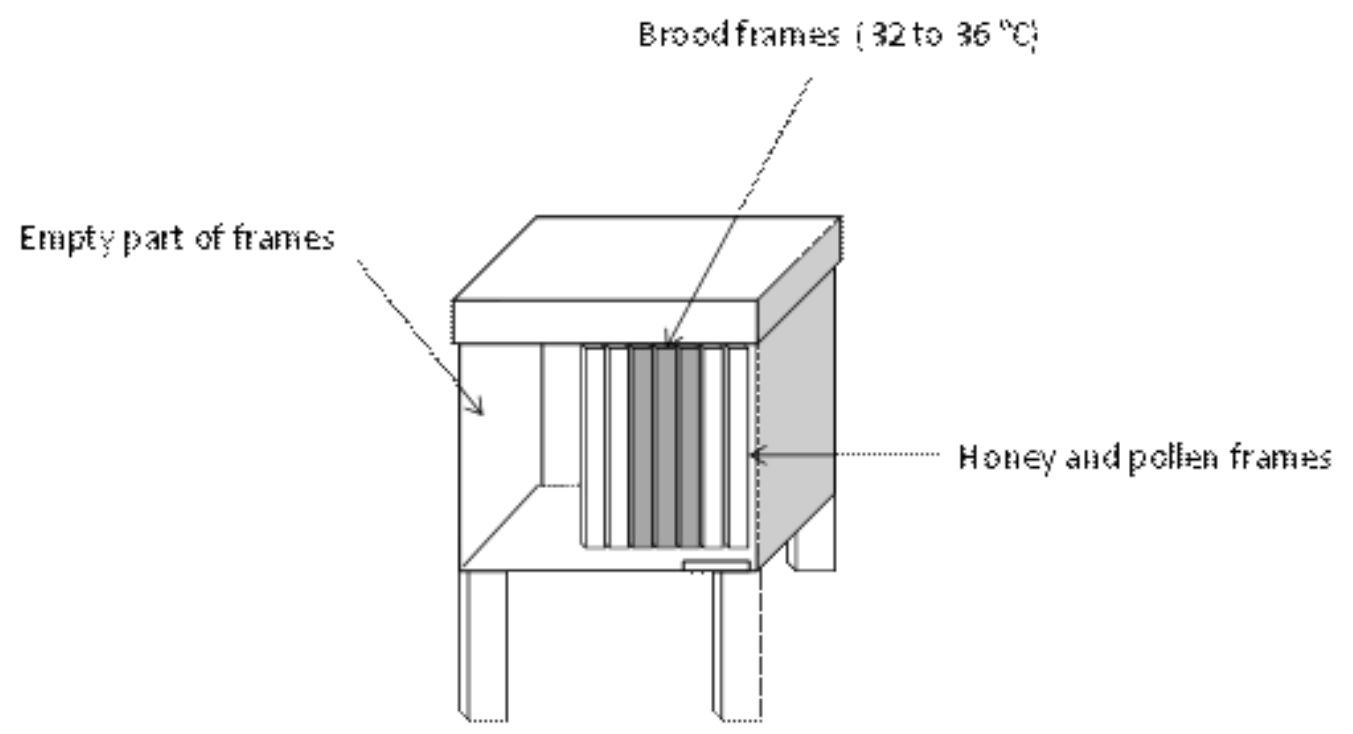

Fig. 4. Parts of a beehive.

\section{Diseases presence}

The presence of any diseases within the colonies was recorded every 12 days during the study period.

\section{Temperature readings}

The ambient and internal temperatures at the empty regions of the frames inside the beehive (Fig. 4), were measured using an immediate temperature measuring device (HD 8501. Temperature range from -50 to $+150^{\circ} \mathrm{C}$ ) between 8 and 10 am on different days during the study period. This time was selected because a large increase in the ambient temperature was noted after $10 \mathrm{am}$, which hindered the field work. The empty region of the frames was selected for measuring the internal temperature. This was done because this portion is not actively regulated by the honey bee workers and strongly reflects the contributions of the modifications on the internal temperature of the beehive. Moreover, this region represents the hottest or coldest part of the beehive during the hot or cold seasons, respectively.

\section{Statistical analysis}

The experiment was set up according to a randomized complete block design (RCBD) containing four blocks with the treatments distributed randomly within these blocks. For the aforementioned parameters, ANOVA was performed. The means were compared using
Duncan's multiple range test at a significance level of 0.05 . The correlations between some factors were calculated using a Pearson correlation coefficient $(r)$. The statistical analysis was performed with a SAS 9.1.3 program (SAS Institute, 2004).

\section{RESULTS}

\section{Internal activities of honey bee colonies}

Internal activities of Carniolan honey bee colonies

The Carniolan honey bee colonies were housed in different types of beehives. These bees had the highest mean sealed brood area of $10.04 \mathrm{dm}^{2}$ for the colonies with insulated boxes and the lowest area of $4.56 \mathrm{dm}^{2}$ for normal beehives. The colonies with insulated cover boxes recorded the highest means for all other parameters including the stored honey and bee numbers with means of $18.58 \mathrm{dm}^{2}$ and 7414.00 bees, respectively. The highest mean for stored pollen area was found for insulated beehives with back drawers. The lowest mean areas for stored pollen and stored honey were found in the thermoregulatory and normal beehives, respectively. The lowest mean bee number was 5573.25 bees for normal beehives (Tab. 1). In general, the types of beehives can be arranged according to their performance, as follows: colonies with insulated cover boxes, thermoregulatory beehives, insulated beehives with back 
Table 1.

Brood, pollen and honey areas in $\mathrm{dm}^{2}$ and number of bees,

for housed Carniolan honey bees in different beehive types

\begin{tabular}{ccccc}
\hline \multirow{2}{*}{ Hive type } & Brood area & Pollen area & Honey area & Bee numbers \\
\cline { 2 - 5 } & $6.58 \pm 1.93 \mathrm{~b}^{\star}$ & $0.26 \pm 0.21 \mathrm{a}$ & $15.52 \pm 3.80 \mathrm{~b}$ & $\begin{array}{c}6363.50 \pm \\
592.92 \mathrm{~b}\end{array}$ \\
\hline $\begin{array}{c}\text { Thermoregulatory } \\
\text { beehives }\end{array}$ & $6.96 \pm 1.46 \mathrm{~b}$ & $0.36 \pm 0.22$ a & $15.26 \pm 2.48 \mathrm{~b}$ & $\begin{array}{c}5978.75 \pm \\
763.44 \mathrm{c}\end{array}$ \\
\hline $\begin{array}{c}\text { Insulated beehives } \\
\text { with back drawer }\end{array}$ & $10.04 \pm 2.96 \mathrm{a}$ & $0.27 \pm 0.20 \mathrm{a}$ & $18.58 \pm 2.81 \mathrm{a}$ & $\begin{array}{c}7414.00 \pm \\
861.86 \mathrm{a}\end{array}$ \\
\hline $\begin{array}{c}\text { Insulated cover } \\
\text { boxes }\end{array}$ & $4.56 \pm 2.21 \mathrm{c}$ & $0.31 \pm 0.31 \mathrm{a}$ & $10.04 \pm 1.98 \mathrm{c}$ & $\begin{array}{c}5573.25 \pm \\
362.006 \mathrm{~d}\end{array}$ \\
\hline \begin{tabular}{c} 
Normal beehives \\
\hline
\end{tabular}
\end{tabular}

*Means followed by the same letter in the same column are not significantly different according to Duncan's Multiple Range Test at the significance level of 0.05 .

drawers, and normal beehives. Significant differences were found between all beehive types for all measured parameters except for stored pollen area $(\mathrm{df}=3$ and $\mathrm{P}=0.0001$, for brood area; $F=42.01$, for honey area; $F=62.12$, for bee numbers; $F=55.22$ while for pollen area; $F=1.18$ and $P=0.3183$ ). The colonies provided with insulated cover boxes differed significantly from the other beehive types in their sealed brood, stored honey, and bee numbers. No significant differences were detected between the means of either sealed brood or stored honey areas in the thermoregulatory beehives or insulated beehives with back drawers.

Internal activities of Yemeni honey bee colonies The mean performance parameters and their statistical analyses are summarized in Table 2. The highest mean sealed brood area was $12.22 \mathrm{dm}^{2}$ for the thermoregulatory beehives, and the lowest was $10.23 \mathrm{dm}^{2}$ for the insulated beehives with back drawers. The highest mean stored pollen area was $3.19 \mathrm{dm}^{2}$ for the insulated beehives with back drawers, and the lowest was $2.19 \mathrm{dm}^{2}$ for the thermoregulatory beehives. The honey bee colonies with normal beehives had the highest mean stored honey area at $8.44 \mathrm{dm}^{2}$. The insulated beehives with back drawers had the lowest mean stored honey area $\left(6.62 \mathrm{dm}^{2}\right)$. The highest mean bee number was 9258.00 bees for the thermoregulatory beehives, and the lowest was 8886.00 bees for the insulated beehives with a back drawer. The thermoregulatory beehives proved the best beehive type, followed by the insulated cover boxes, the normal beehives, and finally the insulated beehives with a back drawer.

Significant differences were detected between the beehive types for most parameters ( $\mathrm{df}=3$, $P=0.0001$, for brood area; $F=23.84$, for pollen area; $F=9.12$, for honey area; $F=37.41$, for bee numbers; $F=50.59$ ).

\section{Comparison between the two races}

The Carniolan honey bee colonies housed in different types of beehives exhibited better stored honey areas than the Yemeni honey bee colonies. In the other parameters, the Yemeni honey bee colonies proved better adapted than the Carniolan honey bee colonies. Significant differences ( $\mathrm{df}=7, \mathrm{P}=0.0001$; for brood area; $F=106.15$, for pollen area; $F=142.27$, for honey area; $F=191.76$, for bee numbers; $F=405.78$ ) were found between the two races in all measured parameters for all beehive types.

\section{Foraging activity}

For the Carniolan honey bees, the highest mean foraging was 43.87 bees for the colonies with insulated cover boxes, and the lowest was 23.05 bees for the insulated beehives with a back drawer. For the Yemeni honey bees, the highest mean was 81.81 bees for colonies 
with the insulated cover boxes, and the lowest was 68.41 bees for the insulated beehives with a back drawer (Tab. 3). Significant differences (df $=7, P=0.0001, F=127.69$ ) were found between most beehive types.

A weak negative correlation ( $r=-0.09$ ) was found between the foraging activity and the temperature. A moderately positive correlation $(r=0.54)$ was found between the foraging activity and the brood area. A strong positive correlation ( $r=0.70$ ) was observed between the foraging activity and bee numbers. In addition, a moderately positive correlation ( $r=0.63$ ) was found between the foraging activity and the stored pollen area, and a weak negative correlation ( $r=-0.49$ ) was found between the foraging activity and the stored honey area. All correlations were significant $(P<0.05)$.

\section{Emergence rate}

For the Carniolan honey bees, the lowest mean was $96.13 \%$ for the thermoregulatory beehives, and the highest mean was $99.14 \%$ for the the insulated cover boxes. The highest mean for the Yemeni honey bees was $100 \%$ for the the insulated cover boxes, and the lowest mean was $97.84 \%$ for the normal beehives. The emergence rate of the imago honey bees from the sealed brood ranged from 96.13 to $100 \%$ for the two races (Tab. 4). In general, no significant differences were noted between any beehive types except between the Carniolan honey bees housed in thermoregulatory beehives and the other beehive types ( $\mathrm{df}=7, \mathrm{P}$ $=0.0675, F=2.01$ ).

Table 2.

Brood, pollen, and honey areas in $\mathrm{dm}^{2}$ and number of bees for housed Yemeni honey bees in different beehive types

\begin{tabular}{ccccc}
\hline \multirow{2}{*}{ Hive type } & Brood area & Pollen area & Honey area & Bee numbers \\
\cline { 2 - 5 } & $12.22 \pm 1.61 \mathrm{a}^{*}$ & $2.19 \pm 1.25 \mathrm{~b}$ & $6.79 \pm 0.54 \mathrm{c}$ & $\begin{array}{c}9258.00 \pm \\
252.15 \mathrm{a}\end{array}$ \\
\hline $\begin{array}{c}\text { Thermoregulatory } \\
\text { beehive }\end{array}$ & $10.23 \pm 0.61 \mathrm{c}$ & $3.19 \pm 0.58 \mathrm{a}$ & $6.62 \pm 0.64 \mathrm{c}$ & $\begin{array}{c}8886.00 \pm \\
105.44 \mathrm{~b}\end{array}$ \\
\hline $\begin{array}{c}\text { Insulated beehives } \\
\text { with back drawer }\end{array}$ & $12.06 \pm 1.09 \mathrm{ab}$ & $2.46 \pm 1.11 \mathrm{~b}$ & $7.92 \pm 1.05 \mathrm{~b}$ & $\begin{array}{c}9195.00 \pm \\
149.56 \mathrm{a}\end{array}$ \\
\hline $\begin{array}{c}\text { Insulated cover } \\
\text { boxes }\end{array}$ & $11.57 \pm 1.13 \mathrm{~b}$ & $2.98 \pm 0.74 \mathrm{a}$ & $8.44 \pm 1.23 \mathrm{a}$ & $\begin{array}{c}8948.75 \pm \\
88.49 \mathrm{~b}\end{array}$ \\
\hline $\begin{array}{c}\text { Normal beehives } \\
\text { *Means followed by the same letter in the same column are not significantly different according to } \\
\text { Duncan's Multiple Range Test at the significance level of 0.05. }\end{array}$ & & \\
\hline
\end{tabular}

Foraging activity (number of forager bees)

Table 3.

of Yemeni and Carniolan honey bee colonies

\begin{tabular}{ccc}
\hline \multirow{2}{*}{ Hive type } & \multicolumn{2}{c}{ Mean \pm SD } \\
\cline { 2 - 3 } & Carniolan honey bees & Yemeni honey bees \\
\hline Thermoregulatory beehive & $26.27 \pm 19.36 \mathrm{f}^{\star}$ & $77.83 \pm 20.09 \mathrm{ab}$ \\
\hline $\begin{array}{c}\text { Insulated beehives with } \\
\text { back drawer }\end{array}$ & $23.05 \pm 14.29 \mathrm{f}$ & $68.41 \pm 20.27 \mathrm{c}$ \\
\hline Insulated cover boxes & $43.87 \pm 28.67 \mathrm{~d}$ & $81.81 \pm 20.02 \mathrm{a}$ \\
\hline Normal beehives & $33.87 \pm 25.25 \mathrm{e}$ & $72.63 \pm 21.08 \mathrm{bc}$ \\
\hline
\end{tabular}

*Means with the same letter are not significantly different according to Duncan's Multiple Range Test at the significance level of 0.05 . 
Diseases presence

For Carniolan honey bees, varroa mite was recorded only in one colony of thermoregulatory beehives while chalk brood disease was found in two colonies with insulated cover boxes and one colony of insulated beehives with a back drawer. For Yemeni honey bee colonies, varroa mite was found only in one thermoregulatory beehive and no other diseases were observed.

\section{Temperature readings}

The ambient and internal temperatures were recorded between 8 and 10 am for the colonies housed in the different types of beehives (Tab. 5). The highest internal temperatures were found in the normal beehives, followed by the colonies with insulated cover boxes, the insulated beehives with a back drawer, and finally the thermoregulatory beehives.
No significant differences were noted between the thermoregulatory beehives and the insulated beehives with a back drawer or between the colonies with insulated cover boxes and the normal beehives, when the ambient temperatures reached 36.1 and $36.5^{\circ} \mathrm{C}$. When the ambient temperature was $38.4^{\circ} \mathrm{C}$, no significant differences were noted between the colonies with insulated cover boxes and the normal beehives, while significant differences were found between the insulated beehives with a back drawer and the thermoregulatory beehives. However, significant differences were found between the reduction rates for all beehive types ( $\mathrm{df}=3$, for reduction rates; $P=0.0001, F=41.58$ at $36.1^{\circ} \mathrm{C} ; P=0.0007$, $F=8.55$ at $36.5^{\circ} \mathrm{C} ; P=0.0001, F=16.78$ at $\left.38.4^{\circ} \mathrm{C} ; \mathrm{P}=0.0001, \mathrm{~F}=34.73\right)$.

Table 4.

Emergence rate (\%) of Yemeni and Carniolan honey bee colonies

\begin{tabular}{|c|c|c|}
\hline \multirow{2}{*}{ Hive type } & \multicolumn{2}{|c|}{ Mean \pm SD } \\
\hline & Carniolan honey bees & Yemeni honey bees \\
\hline Thermoregulatory beehive & $96.13 \pm 5.37 b *$ & $99.70 \pm 0.91$ a \\
\hline $\begin{array}{l}\text { Insulated beehives with back } \\
\text { drawer }\end{array}$ & $98.90 \pm 1.68$ a & $99.16 \pm 1.39 a$ \\
\hline Insulated cover boxes & $99.14 \pm 1.81$ a & $100.00 \pm 0.00 a$ \\
\hline Normal beehives & $99.07 \pm 1.32 \mathrm{a}$ & $97.84 \pm 3.82 a b$ \\
\hline
\end{tabular}

Table 5.

Contribution of beehive type concerning the internal temperature under shaded conditions and between 8 to $10 \mathrm{am}$

\begin{tabular}{ccccc}
\hline \multirow{2}{*}{$\begin{array}{c}\text { Ambient } \\
\text { temperature } \\
\left({ }^{\circ} \mathrm{C}\right)\end{array}$} & $\begin{array}{c}\text { Thermoregula- } \\
\text { tory beehive }\end{array}$ & $\begin{array}{c}\text { Insulated } \\
\text { beehive with } \\
\text { back drawer }\end{array}$ & $\begin{array}{c}\text { Insulated cover } \\
\text { box }\end{array}$ & $\begin{array}{c}\text { Normal } \\
\text { beehives }\end{array}$ \\
\hline 36.1 & $33.03 \pm 0.19 \mathrm{~b} *$ & $33.53 \pm 0.13 \mathrm{~b}$ & $34.72 \pm 0.34 \mathrm{a}$ & $34.80 \pm 0.43 \mathrm{a}$ \\
\hline 36.5 & $33.33 \pm 0.29 \mathrm{~b}$ & $33.72 \pm 0.21 \mathrm{~b}$ & $35.16 \pm 0.38 \mathrm{a}$ & $35.65 \pm 0.16 \mathrm{a}$ \\
\hline 38.4 & $33.72 \pm 0.23 \mathrm{c}$ & $34.53 \pm 0.13 \mathrm{~b}$ & $36.55 \pm 0.35 \mathrm{a}$ & $36.97 \pm 0.29 \mathrm{a}$ \\
\hline $\begin{array}{c}\text { Reduction } \\
\text { rate }(\%)\end{array}$ & $9.78 \pm 0.54 \mathrm{a}$ & $8.26 \pm 0.39 \mathrm{~b}$ & $4.05 \pm 0.53 \mathrm{c}$ & $3.22 \pm 0.49 \mathrm{c}$ \\
\hline $\begin{array}{c}{ }^{*} \text { Means in the same row and followed by the same letter are not significantly different according to } \\
\text { Duncan's Multiple Range Test at the significance level of 0.05. }\end{array}$
\end{tabular}




\section{DISCUSSION}

Internal activities of honey bee colonies

The Carniolan honey bee colonies with insulated cover boxes had the highestmeans for the sealed brood, and honey areas as well as bee numbers. These high means could be explained by the role of the insulated cover boxes in reducing the environmental stress on the honey bee colonies and preserving the steady conditions within the colonies. The high bee numbers mean could be explained by the relatively high mean sealed brood area because the sealed brood represents the next population of workers. In contrast, the relatively high mean stored honey area may be due to the high population of bees that form the foraging force. However, the mean stored pollen area was low due to the scarcity of pollen resources in the study region and the relatively high brood area and bee numbers, which require high pollen quantities. The beehives with a source of humidity, insulation material, or fans outperformed the normal beehives in the sealed brood area, stored honey, and pollen areas. This outperformance may be related to the contribution of these types of beehives toward better reducing environmental stress on the colonies in comparison with normal beehives. In accordance with this interpretation, Al-Kahtani (2003) found that Carniolan colonies provided with BeeCool devices containing solar-powered fans had larger brood areas and stored more pollen than normal colonies. However, the colonies with the insulated cover boxes surpassed those with a source of humidity in most parameters. This trend could be due to the negative impact of humidity within the beehives, which may push the honey bee workers to perform extra activities (i.e., fanning behavior) to adjust the internal humidity till it is within the normal range.

In the case of Yemeni honey bees, the thermoregulatory beehives recorded the highest mean for the brood area and bee numbers. That observation could be explained by the role of such modified beehives in the thermoregulation process within the colonies and the ability of the Yemeni honey bees to adapt to such modified beehives. This result is in agreement with those of Erdogan et al. (2009), who found the highest mean brood area to be in the heated-fan colonies, followed by the heated colonies, and finally the normal colonies. In addition, an increase in the brood production was found for the modified beehives developed with solarpowered systems (Altun, 2012). The thermoregulatory beehives simultaneously had relatively low stored pollen and honey areas, perhaps due to the high food consumption by the bees and broods. However, the present result differs from that of Erdogan et al. (2009), in which the honey yield of the heated-fan colonies was higher than that of either the heated or normal colonies. In contrast, the insulated beehives provided with a back drawer had the smallest brood area and bee numbers and the highest pollen area. Perhaps the Yemeni honey bee workers were unable to adapt to these beehives, and the high pollen area is possibly a natural result of the low brood area and bee numbers. In addition, the results indicated that the normal colonies and the colonies with insulated cover boxes had acceptable results, which could be attributed to the ability of the Yemeni honey bees to tolerate harsh conditions (Abou-Shaara et al., 2012).

In the present study, the Carniolan honey bees stored more honey than the Yemeni honey bees but the Yemeni honey bees stored larger quantities of pollen than the Carniolan honey bees. These findings are in accordance with those of Al-Ghamdi (2002) for the activities of Yemeni and Carniolan honey bees. In general, the beehive type impacted the colony performance because significant differences were detected between the modified and normal beehives. Ellis et al. (2003) also found that modified beehives impacted the number of adult bees and the size of the stored pollen areas.

\section{Foraging activity}

In the present study, better foraging activity was generally associated with the modified beehives when compared with the normal beehives. In accordance with this trend, Erdogan et al. (2009) found that higher flying activity was associated with the modified colonies over that of the normal colonies. The differences in the foraging activities with beehive type within each race 
could be empirically explained by the differences in their performance. The Yemeni honey bees had a higher foraging activity than the Carniolan honey bees. Al-Qarni (2006) measured higher foraging activity for the Yemeni honey bees with means of 89.36 and 104.67 bees compared with the Carniolan honey bees with means of 27.49 and 23.33 bees at 8 and 10 am This result is in agreement with that of Pankiw et al. (2002), who found that the genotype strongly affected the foraging behavior. Thus, the honey bee race influenced the foraging activity. Danka et al. (2006) disagreed as they found no influence of bee race on the flight activity or pollen forager percentages during their study of almond orchards. However, a study by Joshi and Joshi (2010) in which differences were noted in the foraging behavior of various honey bee species relatively agrees with the current findings.

The results uncovered the presence of a negative weak correlation between the foraging activity and the temperature. Cooper and Schaffer (1985) found that the number of pollen foragers decreased under high ambient temperatures. Blazyte-Cereskiene et al. (2010) also found that high ambient temperatures impact the foraging behavior with the lowest foraging activity detected at an ambient temperature of $43^{\circ} \mathrm{C}$. Low ambient temperatures were also found to affect the foraging activity (Joshi and Joshi, 2010). Tan et al. (2012) found that $A$. mellifera reached its highest activity when the ambient temperature was approximately $20^{\circ} \mathrm{C}$. A positive correlation was found between the foraging activity and the brood area, and between the foraging activity and the bee numbers. This evidence also supported that of Beekman et al. (2004), who found that small colonies had lower numbers of foragers returning per minute than large colonies. A moderate positive correlation was found between the foraging activity and the stored pollen area. This correlation could be indirectly explained by the role of the stored pollen in enhancing brood rearing and increasing the colony population, which subsequently increases the foraging activity. In contrast, a weak negative correlation was found between the foraging activity and the stored honey area. The explanation for such a weak correlation may be due to the role of the stored honey abundance in the exchange of the forager bee activities for other activities (e.g., thermoregulation inside the colony) under harsh environmental conditions.

\section{Emergence rate}

Relatively high emergence rates were found for all beehive types and for the two races. These high rates reflect the absence of negative impacts on the honey bee pupae, including internal temperature and relative humidity. This finding was in agreement with the work of Tautz et al. (2003) who found high mean emergence rates from 98 to $100 \%$ for Carniolan broods incubated at temperatures ranging from 32 to $36^{\circ} \mathrm{C}$. In addition, Groh et al. (2004) found low emergence rates (from 0 to $73 \%$ ) for Carniolan broods reared at temperatures of 28, 29, 37, and $38^{\circ} \mathrm{C}$. Honey bees housed in different types of beehives succeeded in maintaining suitable conditions within their nest but expended more or less energy depending on the beehive type.

\section{Diseases presence}

Apart from varroa mite which is considered as a worldwide disease for honey bee colonies, chalk brood disease was found only in three Carniolan honey bee colonies. That may be due to the presence of a water source or due to the failure of honey bee workers in these colonies to perform the effective thermoregulation process. It is known that the presence of fungal diseases within colonies is correlated with elevated humidity (e.g. Flores et al., 1996). In general, the presence of disease was very low for the two races. Thus, modified beehives did not contribute to the prevalence of disease.

\section{Temperature readings}

The results indicated that higher internal temperatures were more closely associated with normal beehives than with modified beehives. The contribution of each beehive type to the internal temperature and to the thermoregulation process were revealed. These results are supported by a study from Al-Kahtani (2003), who found that Carniolan honey bee colonies provided with the BeeCool device had 
lower temperatures than the normal colonies during autumn and winter. This finding contradicted that of Lorenzon et al. (2004), who found a higher internal temperature in the beehives constructed of cement-vermiculite mortar (modified beehives) than in the wooden beehives. The heat stress on the honey bees was higher in the normal beehives than in the modified beehives. One might expect the honey bee workers in normal beehives to waste more energy performing effective thermoregulation than those in the modified beehives. These data were in agreement with Altun (2012), who developed a system to control temperature and humidity within the beehives around the optimum range and found a reduction in the number of bees that perform heating and ventilation processes.

For the other beehive types, the reduction of the internal temperature was due to the presence of insulation material, humidity sources, or fans. In the insulated cover boxes, the reduction in the internal temperature was greater than that in the normal beehive and less than that in the thermoregulatory or insulated beehives with back drawers. However, the Carniolan honey bee colonies with insulated cover boxes performed better than those with the thermoregulatory or insulated beehives with back drawers. The enhanced performance can be explained by the role of the insulated boxes in reducing the internal temperature and preserving the microclimate of the colonies around a steady state. In other words, the presence of the insulated cover boxes reduced the internal temperature and protected the colonies from fluctuations resulting from ambient climatic conditions. However, providing the honey bee colonies with a humidity source and insulation material or fans can help to reduce the internal temperature without preserving the continuous evaporation of water. Additional efforts from the honey bee workers to regulate their own microclimate are needed when there is a continuous evaporation of water. The presence of fans somewhat decreased the workers efforts in regulating their own microclimate than workers in the presence of humidity sources alone.

\section{CONCLUSIONS}

Results of colony performance were impacted by beehive type and honey bee race. Thus, it could be said that the evaluation of any new beehive type should be done using several parameters and different races. The thermoregulatory beehives had better results than other beehive types for Yemeni honey bees. Colonies with insulated cover boxes had better results than other beehive types in the case of Carniolan honey bees. The use of modified beehives is recommended for keeping honey bees under harsh environmental conditions. Modified beehives can be considered a promising trend especially under the current ecological threats for beekeeping.

\section{ACKNOWLEDGMENTS}

Thanks to the Deanship of Scientific Research and the College of Food and Agriculture Science Research Center as well as the Bee Research Unit for providing the necessary materials for the research. Also, we would like to thank Mr. Mohamed S. Younis for feeding the honey bee colonies and for his assistance during the research period, and Mr. Arif R. Single for his help in preparing the modified beehives. Many thanks to the National Plan for Science and Technology for providing the linguistic editing through Nature editing service.

\section{REFERENCES}

Abou-Shaara H. F. (2011) A simple method for feeding bees. Bees for Development Journal 101: 3.

Abou-Shaara H. F. (2012) Notes on water collection by honey bees. Bee World 89(4): 50-51.

Abou-Shaara H. F. Al-Ghamdi A. A. (2012) Studies on wings symmetry and honey bee races discrimination by using standard and geometric morphometrics. Biotechnology in Animal Husbandry 28 (3): 575-584. DOl: 10.2298/BAH1203575A 
Abou-Shaara H. F., Al-Ghamdi A. A., Mohamed A. A. (2012) Tolerance of two honey bee races to various temperature and relative humidity gradients. Environmental and Experimental Biology 10(4): 133138.

Al-Ghamdi A. (2002) The Effect of Pollen Supplementary Feeding on Some Activities of Honeybee Colonies During Summer Season in Riyadh, Saudi Arabia. Saudi Journal of Biological Sciences 9(2): 85 94.

Al-Ghamdi A. (2005) Comparative study between subspecies of Apis mellifera for egg hatching and sealed brood percentage, brood nest temperature and relative humidity. Pakistan Journal of Biological Sciences 8(4): 631-635.

Al-Ghamdi A. A. (2012) Local bee hive with system to control the humidity and temperature inside it. European Patent Office. Patent No. EP2474224. Available at: https://register.epo.org/ application?number=EP1 1000096

Al-Ghamdi A. A., Abou-Shaara H. F. (2012) Langstroth modification. European Patent Office. Patent No. EP2478764. Available at: https://register.epo. org/application?number=EP1 1000497

Al-Kahtani S. N. (2003) Ecological studies on some activities of honeybee colonies under Al-Hassa District conditions Kingdom of Saudi Arabia. MSc Thesis. King Faisal University. Al-Hassa. Saudi Arabia. $191 \mathrm{pp}$.

Al-Qarni A. S. (2006) Tolerance of summer temperature in imported and indigenous honeybee Apis mellifera L. races in central Saudi Arabia. Saudi Journal of Biological Sciences 13(2): 123-127.

Altun A. A. (2012) Remote Control of the Temperature-Humidity and Climate in the Beehives with Solar-Powered Thermoelectric System. Journal of Control Enginering and Applied Informatics 14(1): 93-99.

Beekman M., Sumpter D. J. T., Seraphides N., Ratnieks F. L. W. (2004) Comparing foraging behaviour of small and large honey-bee colonies by decoding waggle dances made by foragers. Functional Ecology 18: 829-835.

Blazyte-Cereskiene L., Vaitkeviciene G., Venskutonyte S., Buda V. (2010) Honey bee foraging in spring oilseed rape crops under high ambient temperature conditions. Zemdirbyste-Agriculture 97(1): $61-70$

Cooper P. D., Schaffer W. M. (1985) Temperature regulation of honey bees (Apis mellifera) foraging in the Sonoran desert. Journal of Experimental Biology 114: 1-15.

Danka R. G., Sylvester H. A., Boykin D. (2006) Environmental Influences on Flight Activity of USDAARS Russian and Italian Stocks of Honey Bees (Hymenoptera: Apidae) During Almond Pollination. Journal of Economic Entomology 99(5): 1565-1570.

Doull K. M. (1976) The effects of different humidities on the hatching of the eggs of honeybees. Apidologie 7: 61 -66. DOl: 10.1051/apido:19760104

Ellis J. D., Delaplane K. S., Hepburn R., Elzen P. J. (2003) Efficacy of Modified Hive Entrances and a Bottom Screen Device for Controlling Aethina tumida (Coleoptera: Nitidulidae) Infestations in Apis mellifera (Hymenoptera: Apidae) Colonies. Journal of Economic Entomology 96(6): 1647-1652.

Ellis M. B., Nicolson S. W., Crewe R. M. Dietemann V. (2008) Hygropreference and brood care in the honeybee (Apis mellifera). Journal of Insect Physiology 54: 1516-1521. DOl: 10.1051/apido:19760104

Erdogan Y., Dodologlu A., Emsen B. (2009) Some physiological characteristics of honey bee (Apis mellifera L.) Housed in heated, fan wooden and insulated Beehives. Journal of Animal and Veterinary Advances 8(8): 1516-1519.

Flores J. M., Ruiz J. A., Ruz J. M., Puerta F., Bustos M., Padilla F., Campano F. (1996) Effect of temperature and humidity of sealed brood on chalkbrood development under controlled conditions. Apidologie 27: 185-192. DOl: 10.1051/apido:19960401 
Groh C., Tautz J., Rossler W. (2004) Synaptic organization in the adult honey bee brain is influenced by brood-temperature control during pupal development. Proceedings of the National Academy of Sciences 101(12): 4268-4273.

Human H., Nicolson S. W., Dietemann V. (2006) Do honeybees, Apis mellifera scutellata, regulate humidity in their nest? Naturwissenschaften 93: 397401.

Jeffree E. P. (1958) A shaped wire grid for estimating quantities of brood and pollen in combs. Bee World 58(3): 105-110.

Joshi N. C., Joshi P. C. (2010) Foraging Behaviour of Apis spp. on Apple Flowers in a Subtropical Environment. New York Science Journal 3(3): 71-76.

Kohno K., Sokabe T., Tominaga M., Kadowaki T. (2010). Honey Bee Thermal/Chemical Sensor, AmHsTRPA, Reveals Neofunctionalization and Loss of Transient Receptor Potential Channel Genes. Journal of Neuroscience 30(37):12219-12229. DOl:10.1523/JNEUROSCI.2001-10.2010

Kronenberg F., Heller H. C. (1982) Colonial thermoregulation in honey bees (Apis mellifera). Journal of Comparative Physiology B 148: 65-76.

Kuhnholz S., Seeley T. D. (1997) The control of water collection in honey bee colonies. Behavioral Ecology and Sociobiology 41: 407-422.

Lorenzon M. C. A., Cidreira R. G., Rodrigues E. H. V., Dornelles M. S., Pereira Jr. G. (2004) Langstroth hive construction with cement-vermiculite. Scientia Agricola 61 (6): 573-578.

Meitalovs J., Histjajevs A., Stalidzans E. (2009) Automatic microclimate controlled beehive observation system. Engineering for rural development. In: Proceedings of $8^{\text {th }}$ International Scientific Conference 'Enginieering for Rural Development'. Jelgava, Latvia, 28-29 May 2009. pp. 265-271.

Ohashi M., Okada R., Kimura T., Ikeno H. (2009) Observation system for the control of the hive envi- ronment by the honeybee (Apis mellifera). Behavior Research Methods 41(3): 782-786. DOl: 10.3758/ BRM.41.3.782

Ohashi M., Ikeno H., Kimura T., Akamatsu T., Okada R., Ito E. (2008) Control of hive environment by honeybee (Apis mellifera) in Japan. In: Proceedings of Measuring Behavior 2008. $6^{\text {th }}$ International Conference on Methods and Techniques in Behavioral Research. Maastricht, the Netherlands. 26-29 August 2008. p. 243.

Omholt S. W., Hagen A., Elmholdt O., Rishovd S. (1995) A laboratory hive for frequent collection of honeybee eggs. Apidologie 26: 297-304. DOl: 10.1051/apido:19950404

Omran N. S. M. (201 1) Wintering of Honeybee Colonies (Apis mellifera L.) by Using a New Technique During Winter Season in Sohag Region. Egyptian Journal of Applied Sciences 7(2): 174-182.

Pankiw T., Tarpy D. R., Page R. E. (2002) Genotype and rearing environment affect honeybee perception and foraging behaviour. Animal Behaviour 64: 663-672. D0l:10.1006/anbe.2002.309

SAS Institute (2004): The SAS System Version 9.1.3. SAS Institute. Cary. NC.

Tan K., Yang S., Wang Z., Radloff S. E., Oldroyd B. P. (2012) Differences in foraging and broodnest temperature in the honey bees Apis cerana and A. mellifera. Apidologie 43(6): 618-623. D0l:10.1007/ s13592-012-0136-y

Tautz J., Maier S., Groh C., Rossler W., Brockmann W. (2003) Behavioral performance in adult honey bees is influenced by the temperature experienced during their pupal development. Proceedings of the National Academy of Sciences 100(12): 7343-7347.

Zacepins A., Stalidzans E. (2012) Architecture of automatized control system for honey bee indoor wintering process monitoring and control. In: Proceedings of $13^{\text {th }}$ International Carpathian Control Conference. High Tatras, Slovakia. 28-31 May 2012. pp. 772-775. 